\title{
Land suitability classification for soils of Kannur micro water shed in Chamarajanagar district, Karnataka
}

M. Ravindranaik, V. Siva Parvathi, K. S. Anilkumar and A. Natarajan

MEMBERS OF RESEARCH FORUM:

Corresponding author : M. Ravindranaik, Department of Soil Science and Agricultural Chemistry, University of Agricultural Sciences, Bengaluru (Karnataka) India

Email: ravindranaik.chauhan001

@ gmail.com

Co-authors :

V. Siva Parvathi, Acharya Nagarjuna University, Guntur (A.P.) India

K.S. Anilkumar and A. Natarajan, ICAR-National Bureau of Soil Science and Land Use Planning, R.C. Bengaluru (Karnataka) India
Received : 24.10.2019; Revised : 07.11.2019; Accepted : 16.11.2019

\section{Summary}

The process of land suitability classification is the appraisal and grouping of specific areas of land in terms of their suitability for defined uses. an investigation was carried out for. To evaluate the soils of the micro watershed for land suitability for important crops like ragi, wheat, maize, Bengal gram and cotton. All soils are highly suitable for ragi crop, marginally suitable for Bengal gram, moderately suitable for maize crop and moderately suitable for cotton crop. The land suitability classes in the study area for ragi, Bengal gram, maize and cotton viz., $\mathrm{S}_{1}, \mathrm{~S}_{3}, \mathrm{~S}_{2}$ and $\mathrm{S}_{2}$, respectively.

Key words : Land suitability,Watershed, Pedons

How to cite this article : Ravindranaik, M., Parvathi, V. Siva, Anilkumar, K.S. and Natarajan, A. (2019). Land suitability classification for soils of Kannur micro water shed in Chamarajanagar district, Karnataka. Asian J. Soil Sci., 14 (1\&2) : 42-45 : DOI : 10.15740/HAS/AJSS/14.1and2/42-45. 